\title{
Open review
}

\section{Another perspective on Bennett's (2014) 'Agreement, dependencies, and Surface Correspondence in Obolo and beyond'}

\author{
Bruce Connell \\ Linguistics and Language Studies Program, Glendon College, York University \\ E-mail: bconnell@yorku.ca
}

\section{Introduction}

Bennett (2014) presents an analysis of phonotactic restrictions on nasal consonants in Obolo [ann] within the confines of Optimality Theory (OT) and Surface Correspondence (SC). My intention here is not to challenge Bennett's OT/SC view of nasal consonants as being somehow wrong, though I think such accounts are not very satisfactory in understanding why a language is the way it is. Different theories may describe different aspects of the synchronic behaviour of a language reasonably well, though none perhaps entirely adequately. Rather, given that languages are shaped by a variety of influences, including their history, I look at the comparative and diachronic side of the Obolo data to provide what is both a complementary and alternative view to why the restrictions on nasal Cs in Obolo are what they are.

\section{Situating Obolo}

Obolo, known also as Andoni, is the most divergent language in the Lower Cross (LC) subgroup of Cross River, which is a branch of Benue-Congo. Cross River comprises Lower and Upper Cross (i.e., Central Cross River, CCR), and possibly Ogoni (Connell, to appear). Indications from both lexical evidence and sound correspondences show Obolo to have split off from its parent language (Proto Lower Cross, PLC) before the rest of the group broke up and quite possibly not long after PLC had separated from PCCR. Evidence for this is found in a number of lexical items common to both Obolo and several Upper Cross (UC) languages (or that have been reconstructed to PUC; see Dimmendaal 1978, Sterk, n.d.) that are not (i.e. no longer) found in other LC languages. Since Obolo is the LC language geographically furthest removed from UC, these shared lexical items are not a result of contact, but stem from their common parent. Additionally, there are sound correspondences in which the Obolo reflex appears to be intermediate between the form reconstructed for PCCR and that found in the rest of LC (Connell 1994, 1995, to appear). 


\section{Constraints on nasals in Obolo and the OT/SC account}

The constraints on the occurrence of nasal consonants in Obolo are summed up succinctly by Faraclas (1984), quoted in Bennett (2014): "If the initial consonant is a nasal consonant, the final consonant must also be nasal." (Faraclas 1984: xvi). That is, within syllables only the following patterns are permissible: $\mathrm{NVN}, \mathrm{CVC}, \mathrm{CVN}$, where $\mathrm{N}$ represents any nasal consonant, and $\mathrm{C}$ any oral consonant; $\mathrm{NV}$ and $\mathrm{CV}$ are not ruled out by this formulation, but NVC is. Based on examples from Faraclas (1984) said to show nasality is anticipatory but not perseverative, Bennett (2014) argues that the pattern in Obolo is not mediated by the intervening vowel, and so cannot be due to spreading (adjacency). Rather, he proposes a set of dependency relations between the onset and the coda, and the coda and the nucleus, but with no dependency between the onset of a syllable and the following vowel. In terms of Surface Correspondence Theory, these relations are expressed as follows (Bennett 2014: 157):

a. Non-continuants in the same syllable must correspond

b. Correspondents must agree in nasality (and assimilate to do so, if needed)

c. But, no agreement happens between an oral onset and a nasal coda (TVN syllables occur; something prevents them from harmonising).

\section{Nasal correspondences between Obolo and other LC languages}

The restrictions observed in Obolo are found across the LC group: generally speaking, an initial nasal implies a final nasal $(=$ pattern 1$)$, though the reverse is not true $(\mathrm{CVN}$ is licit $=$ pattern 2). Examples from a representative selection of LC languages, including Obolo, illustrate these patterns in Tables 1 and 2. Non-cognates are included parenthetically.

Table 1: Initial nasal implies final nasal (pattern 1)

\begin{tabular}{|c|c|c|c|c|c|}
\hline & meat & swallow (v.) & elephant & salt & sell \\
\hline Ebughu & ú-nâ & mÈn & ع́-nî & ú-nùy & nर̀ \\
\hline Ekit & ú-nà & mèì & ع́-nì & í-nว̀y & nर̀ \\
\hline Enwang & ú-nà & mìદ̀y & é-nì & ú-nว̀y & nì̀े \\
\hline Ibibio & ú-nâm & mغ̀n & é-nî:n & í-nûy & nàm \\
\hline Iko & ú-nâm & mغ̀y & '́-nìn & ú-nûy & nàm \\
\hline Obolo & á-nàm & měn & É-nì:n & $\left(u^{\prime}-\mathrm{t} \int \mathrm{i}\right)$ & nám \\
\hline
\end{tabular}

Table 2: Final nasal does not imply initial nasal (pattern 2)

\begin{tabular}{|c|c|c|c|c|c|}
\hline & sheep & day & bite & hat & fire \\
\hline Ebughu & é-rôn & ú-sò & ló & tè & ú-kán \\
\hline Ekit & 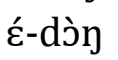 & ú-sù & dú & tì & í-kán \\
\hline Enwang & ع́-ròn & ú-sè & ló & tè & ú-kán \\
\hline Ibibio & é-dôy & ú-sên & dóm & tèm & í-kán \\
\hline Iko & á-ròn & ú-sèn & lóm & (nì̀y) & í-kán \\
\hline Obolo & á-ròn & ú-sèn & lóm & těm & ú-kán \\
\hline
\end{tabular}

There is a small number of words (just three are evident in our database) in LC that are exceptions to pattern 1 in some languages, i.e. they have a nasal as $\mathrm{C} 1$, but an oral consonant as 
$\mathrm{C} 2$ (if there is a consonant). We refer to these as pattern 3 , and give examples in Table 3 . There are several points of interest: first, words with these meanings in Obolo, at least in the available data, are not cognate with the forms elsewhere in LC, making it impossible to judge the status of these exceptions in Obolo; second, there is variation across the group as to whether $\mathrm{C} 2$ is nasal or oral; and third, in each case the $\mathrm{C} 2$ in question is [+dorsal]. ${ }^{1}$ There are two other words that might have been included in Table 3; one of these is 'shake', which in LC typically has a CVCV shape with a nasal in C2; i.e. it follows pattern 1; but in a small number of LC lects it is $\mathrm{CVC}$ and for these $\mathrm{C} 2$ may be oral, e.g. Efai nèk, or nasal, e.g. Iko yày. The second is 'mangrove'; in those LC lects situated on the Atlantic coast (except, interestingly, Obolo) the form for mangrove appears to be adopted from ljo; elsewhere it is derivative of 'salt', and most commonly has a nasal in $\mathrm{C} 2$; e.g. Orọ ù-nùnùy, but Ukwa ǹ-nùnùk.

Table 3: Exceptions to pattern 1 in LC - initial nasal without final nasal (pattern 3).

\begin{tabular}{|c|c|c|c|}
\hline & choose & dance (v.) & short (thing) \\
\hline Ebughu & mèk & nén & (úpók) \\
\hline Ekit & mèk / mèy & nák & ìmók \\
\hline Enwang & mèy & nén & (úpák) \\
\hline Ibibio & mèk & nék & ìmók \\
\hline Iko & (fèt & (zòp) & (íkpíré) \\
\hline Obolo & (gòbô) & (dzǒp) & (yḿgbìdìm) \\
\hline
\end{tabular}

\section{The UC contribution}

The UC data used are from Sterk (n.d.). In UC, words of all three patterns with cognates in LC are attested. Interestingly, those of pattern 1 are not consistent throughout UC, but instead show mixed-pattern correspondences across UC subgroups. I present just three examples, though others are readily available: 'give birth' is NVC in Sterk's (n.d.) groups A-F; H-R 'salt' is NVC in groups A-F, S; and 'swallow (v.)' is NVC in groups A-C, H. These are reconstructed as *mà:tí, *'-nòkkò, and *mè:dí, respectively (though, as indicated, the vowel has been lost in many UC subgroups leaving NVC forms in the groups mentioned). The cognate forms in LC, including Obolo, are all NVN, pattern 1. That is, in Sterk's (n.d.) view nasality has spread perseveratively, from $\mathrm{C} 1$ to $\mathrm{C} 2$. Sterk (n.d.) labels his groups from A to $\mathrm{S}$ following their north to south distribution, so it is also interesting to observe that the more conservative subgroups in UC - for this development and others - are in the north of the UC distribution range. However, there are exceptions; generally speaking as one moves south, encountering languages with pattern 1 becomes more likely. The LC region, where relevant words are strictly pattern 1 (apart from the exceptions noted above), borders the UC region to the south; Obolo, where the pattern appears to be strongest, is at the southwestern extreme of the LC region.

\section{Understanding patterns of nasal-oral consonant co-occurrence restrictions in Obolo}

The distribution of the patterns of NVN/NVC co-occurrence across the Cross River region, suggests the NVN pattern in Obolo today, which Bennett (2014) accounts for through

\footnotetext{
${ }^{1}$ The Ebughu and Enwang forms for 'short' are not cognate with the Ekit and Ibibio forms although superficially they may appear to be; $/ \mathrm{p} /$ in these two lects regularly corresponds with $/ \mathrm{kp} /$ elsewhere in LC, in this case, e.g., Orọ úkpók.
} 
recourse to a Surface Correspondence constraint, is a result of a historical process of perseverative nasal spreading, which has spread gradually or differentially across the region. While it may be the case that perseverative nasalisation is less common or less expected than anticipatory nasalisation, its possibility here is confirmed by the exceptions to pattern 1 given in Table 3; in these the variation in LC is suggestive of perseverative rather than anticipatory spreading. There are alternatives, one being that Sterk's (n.d.) reconstructions should be reversed (rather than perseverative nasalisation there has been anticipatory denasalisation); similarly, the three LC exceptions noted, which show variation (Table 3), could be analysed either as cases of perseverative nasalisation or anticipatory denasalisation. Finally, it is worth noting here that Faraclas's (1984) work, cited above and in Bennett (2014), is based on one dialect of Obolo. There are other varieties, largely situated further east along the Atlantic coast that remain undocumented. Data from these may provide further insight as to how Obolo came to have the NVN/NVC co-occurrence patterns discussed in Bennett (2014).

\section{References}

Bennett, Wm.G. 2014. Agreement, dependencies, and Surface Correspondence in Obolo and beyond. Stellenbosch Papers in Linguistics Plus, Vol. 44: 149-171.

Connell, B. 1994. The Lower Cross languages: a prolegomena to the classification of the Cross River languages. Journal of West African Languages XXIV: 3-46.

Connell, B. 1995. The historical development of Lower Cross consonants. Journalof African Languages and Linguistics 16: 41-70.

Connell, B. To appear. Cross River: A phylogenetic classification of Cross River \& Central Delta, with lexical reconstructions. To appear in V. Vydrine et al. Eds. Towards Proto-Niger Congo. Language Science Press.

Dimmendaal, G.J. 1978. The Consonants of Proto-Upper Cross and Their Implications for the Classification of the Cross River Languages. Scriptie (final essay for the 'doctorandus' degree), University of Leiden.

Faraclas, N.G. 1984. Obolo Grammar. Bloomington: Indiana University Linguistics Club.

Sterk, J.P. n.d. Reconstruction of Proto Upper Cross. 